\title{
Effects of Different Pretreatments and Seed Coat on Dormancy and Germination of Seeds of Senna obtusifolia (L.) H.S. Irwin \& Barneby (Fabaceae)
}

\author{
Stephen I. Mensah ${ }^{1} \&$ Chimezie Ekeke ${ }^{1}$ \\ ${ }^{1}$ Department of Plant Science and Biotechnology, Faculty of Science, University of Port Harcourt, P.M.B. 5323 \\ Choba, Port Harcourt, Rivers State, Nigeria \\ Correspondence: Chimezie Ekeke, Department of Plant Science and Biotechnology, Faculty of Science, University \\ of Port Harcourt, P.M.B. 5323 Choba, Port Harcourt, Rivers State, Nigeria. E-mail: ekeke.uche@uniport.edu.ng
}

Received: February 15, 2016 Accepted: March 4, 2016 Online Published: March 9, 2016

doi:10.5539/ijb.v8n2p77 URL: http://dx.doi.org/10.5539/ijb.v8n2p77

\begin{abstract}
The seed dormancy of Senna obtusifolia was investigated through various methods, namely pretreatments in concentrated sulfuric acid, $2 \%$ potassium nitrate $\left(\mathrm{KNO}_{3}\right), 99 \%$ ethanol, $99 \%$ methanol, and in hydrogen perioxide; examination of the seed coverings; and the determination of water uptake by the seeds in order to ascertain the most effective technique for breaking dormancy and also determine the dormancy type. The results showed that sulfuric acid treatment recorded the highest germination (100\%); followed by $2 \%$ hydrogen peroxide treatment (24\%) in 15 minutes immersion. The methanol and ethanol pretreatments gave $18.33 \%$ and $16.5 \%$ germinations respectively. Pretreatment in $2 \%$ potassium nitrate gave the lowest germination $(8.50 \%)$, while the intact seeds of S. obtusifiolia (control) gave $0 \%$ germination. The anatomy of the seed coat indicated the presence of hard, thickened and specialized cells of cuticle, macrosclereids, osteoscereids, and disintegrated parenchyma layers. The water uptake of intact seeds was low (13.5\%) after $24 \mathrm{hr}$ imbibitions. These findings revealed that the seed coat acts as barrier to germination by preventing water absorption, possibly gaseous diffusion in and out of the seed and conferring mechanical resistance to the protrusion of embryo. Pretreatments, such as immersion in $\mathrm{H}_{2} \mathrm{SO}_{4}$ will soften the seed coat and permit germination. Seed dormancy in S. obtusifolia can be considered of physical nature and classified as physical dormancy. The results obtained in this study may serve as useful information in the production and improvement of $S$. obtusifolia seedlings, as knowledge on seed dormancy and germination is a critical factor and requirements to the understanding of the propagation of this plant either in situ or ex-situ, in view of the economic potentials/attributes of this species.
\end{abstract}

Keywords: Dormancy, Sulfuric acid, S. obtusifolia, germination, seed coat anatomy, water uptake

\section{Introduction}

Senna obtusifolia (L.) H. S. Irwin \& Barne (= Cassia obtusifolia L.) belongs to the subfamily Caesalpinioideae and family Fabaceae (Hutchison \& Dalziel, 1954; Akobundu \& Agyakwa, 1988). S. obtusifolia is native to southern USA, Mexico and tropical America. It grows in disturbed sites, waste area, riparian zone banks of watercourses), floodplains, drainage channels, open woodlands, fallow land, crops and pastures in wetter tropical and subtropical environments (Harry-O'kuru, Payne-Wah, \& Busman, 2012; Irwin \& Barneby, 2016).

$S$. obtusifolia is known for its medicinal values, agricultural, industrial and ethno-medicinal purposes. Phytochemical investigations of the plant parts revealed the presence of medicinal compounds (phenolic compound anttraquinone, naphthopyrone glycosides) used for the treatment of eye inflammation, phtophobia, lacrimation, lowering of blood pressure, reduction of cholesterol level, bacterial and fungal infections, gonorrhoea, pneumonia, urinary tract infections and mycotic infections (Ettu, Senjobi, \& Ilusanya, 2011; El-Morsy, 2013; Sushma \& Sardana, 2013; Kim et al., 2011). The plant parts are good sources of different colour (black, blue, and orange) of dyes (Irwin \& Barneby, 2016). Also extracts from the plants have been reported to inhibit some bacteria strains and fungal species (Ettu et al., 2011; El-Morsy, 2013; Sushma \& Sardana, 2013; Kim et al., 2011).

Physiologically, a seed provided with adequate water, sufficient oxygen for normal aerobic metabolism and optimal temperature within physiological limits, but does not germinate is termed "dormant" (Berrie, 1984). Seed dormancy is an important evolutionary factor in plants, ensuring their survival in unfavourable conditions and 
allowing them to germinate when the chances of survival for the young seedlings are at the greatest (Johnson and Raven, 2002).

Seeds of S. obtusifolia exhibit some degree of dormancy expressed by low or no germination and this may be attributed to seed dormancy. The germination of the seeds of $S$. obtusifolia has continued to be problematic and the seeds may require different scarification methods and exogenous treatments with chemical to break dormancy and enhance germination, as have been reported for other species (Tambari \& Aminu, 2015; Al-Menaie, 2010; Ramamoorthy, 2005; Rolston, 1978; Nalawadi, 1977; Asghar, Ali, \& Mozhgan, 2014; Emongor, Mathowa, \& Kabelo, 2004; Irfan et al., 2013; Ajiboye, 2010; Idu, Omonhinmin, \& Onyibe, 2007; Salehi, 2008; Corbineau, Gouble, Lecat, \& Come, 1991; Asghar et al., 2014; Mohammad, Faezeh, \& Vajihe, 2014; Gregorio, José, \& Pedro, 2012; Yushi, Kouhei, Tomoya, Takashi, \& Mari, 2008). Studies on pre-treatment methods to break dormancy in S. obtusifolia seeds have not received desired attention.

This study therefore, intends to identify the best pre-treatment methods to break seed dormancy, promote germination of Senna obtusifolia seed and determine the nature of dormancy in view of the economic, medicinal and agricultural potentials of this plant.

\section{Materials and Methods}

\subsection{Source of Materials}

The matured seeds of S. obtusifolia used for this study were obtained from International Institute for Tropical Agriculture (IITA) Ibadan, Nigeria. The seeds were harvested in 2014 and stored dry in a glass container and kept in the refrigerator. Seeds were subsequently collected for investigations when necessary. The germination study commenced in the month of August, 2014.

\subsection{Viability Test by Floating Method}

The viability of the seeds of $S$. obtusifolia was determined by floating the intact seeds in water. The viable seeds settled at the bottom of the container, while the other seeds floated to the top and were considered non-viable. The seeds that settled at the bottom of the container were used for the experiments.

\subsection{Determination of Water Uptake in Intact Seeds}

The seeds of $S$. obtusifolia were properly cleaned with tissue paper to remove any dirt. The cleaned, dried seeds were weighed and thereafter placed in petri dish and immersed in distilled water, incubated individually for 1,4 , 8 and $24 \mathrm{hrs}$ at in the dark. After the desired time, the dishes were removed and water adhering to the surface of the seeds was blotted with tissue paper and the weight subsequently determined. The water uptake after a specific period of imbibitions was determined as noted by Mensah (1984).

\subsection{Pretreatment Methods}

The seeds were pre-treated in concentrated sulfuric acid, 2\% Potassium nitrate, $99 \%$ methanol, $99 \%$ ethanol and Hydrogen peroxide for 2munities, 4 minutes, 15 minutes, 20minutes and 30minutes differently in each of the chemical. At the end of this pretreatment time the seeds were washed severally in distilled water and used for the subsequent germinations.

\subsection{Germination Procedures}

For each treatment carried out, four replicates of 20 seeds per replicate were put in petri dish lined with Whatman filter paper, moistened with $5 \mathrm{ml}$ of distilled water and wrapped with aluminium foil. The seeds were observed daily and watered as deem appropriate. Germination counts were recorded daily, and final count was recorded after 14 days of incubation at $30^{\circ} \mathrm{C}$. Germination was scored when radicle protrudes from the seed coat. For all the different treatments, control experiments were set-up alongside.

\subsection{Germination of Intact Seeds (Control)}

The intact Seeds were germinated without any treatment or pretreatment as described in the germination procedures. This was done to ascertain the germination potentials of intact viable seeds.

\subsection{Statistical Analysis}

The data generated were subjected to statistical analysis to determine the mean, standard deviation and level of significance using Microsoft Excel 2010.

\subsection{Seed Coat Analysis}

Dry seeds were collected from the specimens collected from IITA, fixed in FAA (formalin, acetic acid and alcohol) for $12 \mathrm{hrs}$. Thereafter, the specimens were dehydrated in series of different percentages of ethanol $(30 \%$ and $50 \%)$ 
and stored in 70\% ethanol and sectioned (Agbagwa, Okoli \& Ndukwu, 2007). The sections were stained in 1\% Safranin red for two minutes, counter-stained with Alcian blue, mounted on a slide, viewed and photographed with Optika B-1000 FL LED microscope

\section{Results}

\subsection{Pretreatment with Sulfuric Acid $\left(\mathrm{H}_{2} \mathrm{SO}_{4}\right)$}

In tetraoxosulphate (IV) acid, the germination varied from $14.0 \%$ at 2 minutes pretreatment to $100 \%$ germination at 15-30 minutes pretreatment durations (Figure 1a). Between 2 -10minutes pretreatment time, there is significant difference in the percentage germination (Figure 1a and Table 2). However, beyond 10minutes, no significant difference in germination was observed and the percentage germinations were similar. The results indicate that the maximum pretreatment time in tetraoxosulphate (IV) acid is 15 minutes. The intact seeds (control) gave $0 \%$ germination. The results showed that for the durations of pretreatment, the germination percentage in concentrated $\mathrm{H}_{2} \mathrm{SO}_{4}$ increased with increasing time and there is significant difference in the percentage germination (Table 1). However, the maximum germination was reached after $15 \mathrm{mins}$ pre-treatment duration. This finding conforms to previous works on S. obtusifolia and other related species. For instance, Tambari and Aminu (2015) noted 73.32\% germination in seeds of $S$. obtusifolia after $15 \mathrm{mins}$ of pre-treatment in $\mathrm{H}_{2} \mathrm{SO}_{4}$, Afshar et al.(2014) noted that the dormant seeds of Canna indica L. (Cannaceae) when pretreated with $\mathrm{H}_{2} \mathrm{SO}_{4}$ showed maximum germination of 95\% after three and four hours pretreatment. Mensah and Agbagwa (2004) reported that chemical scarification with concentrated $\mathrm{H}_{2} \mathrm{SO}_{4}$ was very potent in breaking seed dormancy of Gmelina arborea. It is not in all species that $\mathrm{H}_{2} \mathrm{SO}_{4}$ has been reported to break seed dormancy and promote germination. Msaakpa et al. (2013) noted that $\mathrm{H}_{2} \mathrm{SO}_{4}$ was not effective in the enhancement of germination of Castor (Ricinus communis) seeds.

Table 1. Effect of Soaking Time on Percentage Germination of Senna obtusifia Seeds

\begin{tabular}{lcccccc}
\hline \multirow{2}{*}{ Treatment } & \multicolumn{5}{c}{ Treatment time/duration (minutes) } \\
\cline { 2 - 7 } & $\mathbf{2}$ & $\mathbf{4}$ & $\mathbf{1 0}$ & $\mathbf{1 5}$ & $\mathbf{2 0}$ & $\mathbf{3 0}$ \\
\hline Sulfuric acid & $14.0 \pm 0.71^{\mathrm{d}}$ & $48.33 \pm 1.03^{\mathrm{c}}$ & $92.0 \pm 0.89^{\mathrm{b}}$ & $100 \pm 0.00^{\mathrm{a}}$ & $100 \pm 0.00^{\mathrm{a}}$ & $100 \pm 0.00^{\mathrm{a}}$ \\
$99 \%$ Ethanol & $16.5 \pm 1.05^{\mathrm{b}}$ & $12.0 \pm 0.95^{\mathrm{a}}$ & $12.17 \pm 1.17^{\mathrm{a}}$ & $10.33 \pm 1.03^{\mathrm{a}}$ & $10.17 \pm 0.84^{\mathrm{a}}$ & $10.17 \pm 1.17^{\mathrm{a}}$ \\
$99 \%$ Methanol & $16.5 \pm 1.05^{\mathrm{e}}$ & $18.33 \pm 1.033^{\mathrm{d}}$ & $12.17 \pm 1.17^{\mathrm{c}}$ & $14.0 \pm 0.89^{\mathrm{bc}}$ & $10.17 \pm 1.33^{\mathrm{a}}$ & $8.17 \pm 0.75^{\mathrm{a}}$ \\
$2 \%$ Potassium nitrate & $8.0 \pm 0.63^{\mathrm{cd}}$ & $8.5 \pm 0.548^{\mathrm{c}}$ & $5.5 \pm 0.548^{\mathrm{b}}$ & $4.33 \pm 0.52^{\mathrm{a}}$ & $4.17 \pm 0.41^{\mathrm{a}}$ & $4.17 \pm 0.41^{\mathrm{a}}$ \\
Hydrogen peroxide & $16.17 \pm 0.75^{\mathrm{f}}$ & $18.0 \pm 0.63^{\mathrm{e}}$ & $20.33 \pm 1.63^{\mathrm{db}}$ & $24.0 \pm 0.63^{\mathrm{c}}$ & $20.0 \pm 0.63^{\mathrm{b}}$ & $10.0 \pm 0.63^{\mathrm{a}}$ \\
Control & 0 & 0 & 0 & 0 & 0 & 0 \\
\hline
\end{tabular}

Note: For each pretreatment chemical the values with the same alphabets are not significantly different.

\subsection{Pretreatment with 99\% Ethanol}

In $99 \%$ ethanol, the germination ranged from $10.17 \%$ to $16.50 \%$ when compared with the control $(0.0 \%)$. The maximum germination was recorded for 2 minutes pretreatment (Figure 1b). Here, there is progressive decrease in the percentage germination with increasing time of pre-treatment. Pre-treatment with ethanol only gave slight germination and can be considered ineffective method of breaking dormancy in seed of S. obtusifolia, it may be suggested that $99 \%$ ethanol serve more as a fixative which kills and preserve the specimen. However, ethanol has been reported to have stimulatory effects on the germination of seeds of other plant species (Taylorson \& Hendricks, 1979; Bewley \& Black, 1982; Ikeda, 1963).

\subsection{Pre-Treatment with $99 \%$ Methanol}

The germination of the seeds pretreated with $99 \%$ methanol ranged from $8.17 \%$ to $18.33 \%$, while the control (untreated seeds) recorded $0.0 \%$. The maximum germination of $18.33 \%$ was recorded in seeds pretreated for 4 minutes (Figure 1c), and thereafter germination decreased progressively to $8.17 \%$ after 30 minutes of pre-treatment duration. In contrast to the slight germination observed in S. obtusifolia seeds, methanol has been reported to enhance significant germination of Tamarindus indica L seeds (Ajiboye, 2010) and seeds of Hura cepitans (Idu, et al., 2007). It is therefore suggest that this level of methanol concentration (99\%) is injurious to the seeds of S. obtusifolia.

\subsection{Pre-Treatment with $2 \%$ Potassium Nitrate $\left(\mathrm{KNO}_{3}\right)$}

The trend of the germination of the seeds of S. obtusifolia pre-treated in $2 \%$ potassium nitrate followed the same sequence with that of the $99 \%$ methanol. The germination varied from $4.17 \%$ to $8.50 \%$ (Figure 1d), while the 
control recorded $0.0 \%$ germination. There was slight increase germination from 2 minutes $(8.0 \%)$ to 4 minutes $(8.50 \%)$ pre-treatment duration, thereafter, the germination progressively decreased to $4.17 \%$ after 30 minutes pretreatment duration. The ineffectiveness of $\mathrm{KNO}_{3}$ to enhance the germination $S$. obtusifolia seeds is supported by the report of Mohammad et al. (2014), they observed that $\mathrm{KNO}_{3}$ did not significantly influence seed germination of Capsella bursa-pastoris (Brassicaceae). However findings from other reports indicated that $\mathrm{KNO}_{3}$ effectively improved seed germination in Calotropis persica Gand. (Apocyanaceae) (Asghar et al., 2014), Medicago species (Hamid \& Seyed, 2006), Gmelina arborea (Mensah \& Agbagwa, 2004), Capsicum frutescens L (Mensah and Agbagwa, 2001).

It may be argued that the ineffectiveness of $\mathrm{KNO}_{3}$ in breaking seed dormancy and promoting germination in seeds of $S$. obtusifolia may be correlated with the design of the experiment and concentration of $\mathrm{KNO}_{3}$ applied. Mensah and Agbagwa $(2001 ; 2004)$ noted that germination in $\mathrm{KNO}_{3}$ solution significantly enhanced germination. In Polygonium persicaria L. seeds, percentage germination varies with experimental design, namely - exposing seeds in water germination for some time intervals before germinating in $\mathrm{KNO}_{3}$; imbibing seeds in $\mathrm{KNO}_{3}$ for some time before germination in water; or germinating seeds directly in $\mathrm{KNO}_{3}$ without any pre-treatment have different effect on germination (Mensah, 1984).
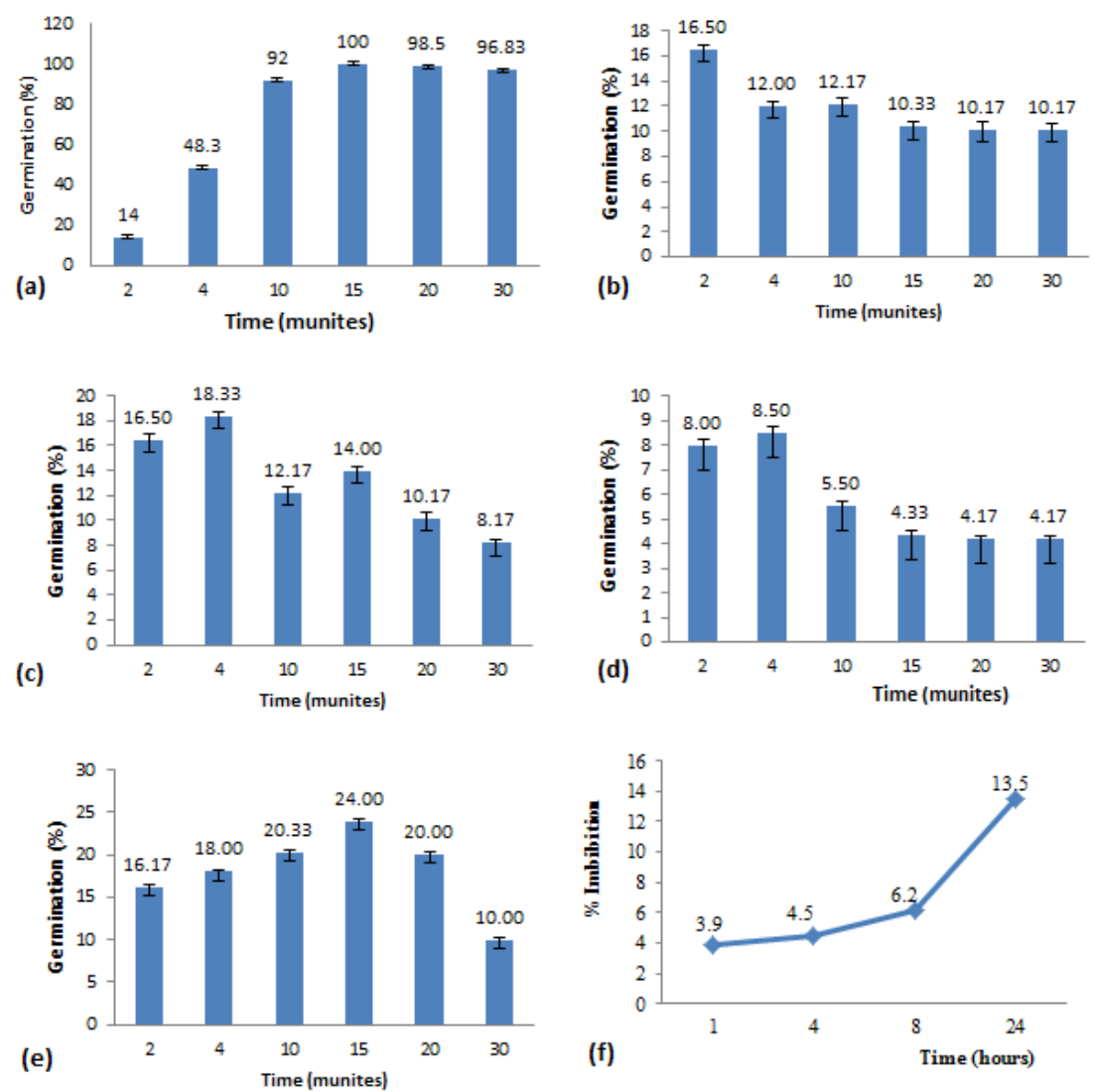

Figure 1. Effect of different chemical treatments on the germination of Senna obtusifolia seeds; (a) Tetraoxosulphate (IV) acid; (b) 99\% Ethanol; (c) 99\% Methanol; (d) 2\% Potassium nitrate; (e) Hydrogen peroxide; (f) Distilled water and (f) Percentage imbibitions

\subsection{Pretreatment with Hydrogen Peroxide $\left(\mathrm{H}_{2} \mathrm{O}_{2}\right)$}

The germination of $S$. Obtusifolia varied from $10.0 \%$ in 30 minutes $\mathrm{H}_{2} \mathrm{O}_{2}$ pre-treatment to $24.0 \%$ in 15 minutes pre-treatment duration (Figure 1e), while the control gave $0.0 \%$ germination. The germination of the seeds increased progressively from 2 minutes $(16.17 \%)$ pre-treatment period to 15 minutes $(24 \%)$ and thereafter, decreased to $10.0 \%$ for 30 minutes duration. In contrast to other studies, $\mathrm{H}_{2} \mathrm{O}_{2}$ was reported to increase germination of pea seeds (Gregorio et al., 2012); in cereals (Yushi et al., 2008); effectively improve germination of Zinnia elegans (Jacq) seeds (Dorota, 2014), and stimulated germination in seeds of Fagus orientalis (Afsaneh, Farshd, 
Bahram, Katayoun \& Mohamad-Ali, 2012).This study suggests that $\mathrm{H}_{2} \mathrm{O}_{2}$ is also not an effective pretreatment method for dormancy breaking in S. obtusifolia.

\subsection{Water Uptake}

The rate of water uptake of the initial dry weight of intact seeds is shown in Figure 1f. The rate of water uptake progressively increased from 3.9\% after 1hour exposure to 13.5\% after 24 hour exposure (Figure 1f), indicating low water absorption/ imbibitions by the intact seeds. The result implies that the seed coat might retard or impede water uptake into the seeds. Kaufmann and Ross (1970) noted that germination is not possible in most species unless the water potential of the seed is greater than $-1.5 \mathrm{MPa}$. Berrie and Drennan (1971) reported $60-78 \%$ water uptake after $24 \mathrm{hrs}-144 \mathrm{hrs}$ exposure to water in tomato seeds at $24^{\circ} \mathrm{C}$. Mensah and Agbagwa (2004), observed $70 \%$ and $12 \%$ water uptake of the initial dry weight in scarified and un-scarified seeds respectively of Gmelina arborea. In Polygonum persicaria, water uptake of the intact achenes and those with tips cut off were $30 \%$ and $37 \%$ respectively, after $16 \mathrm{hrs}$ incubation (Mensah, 1984).The result of the water uptake in the seed coat of $S$. obtusifolia indicated that the seed coat/coverings of this species is hard and largely impermeable to water, possibly diffusion of gases and offering mechanical resistance/barrier to germination.

\subsection{Seed Coat Anatomy}

The anatomy of the seed coat indicated the presence of water and gas impermeable tissues consisting of cuticle, macrosclerids, and osteosclereids (Figure 2) which might interfere with the processes like water uptake or regulate gaseous exchange. Consequently the seed coat may function to regulate germination by offering physical resistance to embryo growth.

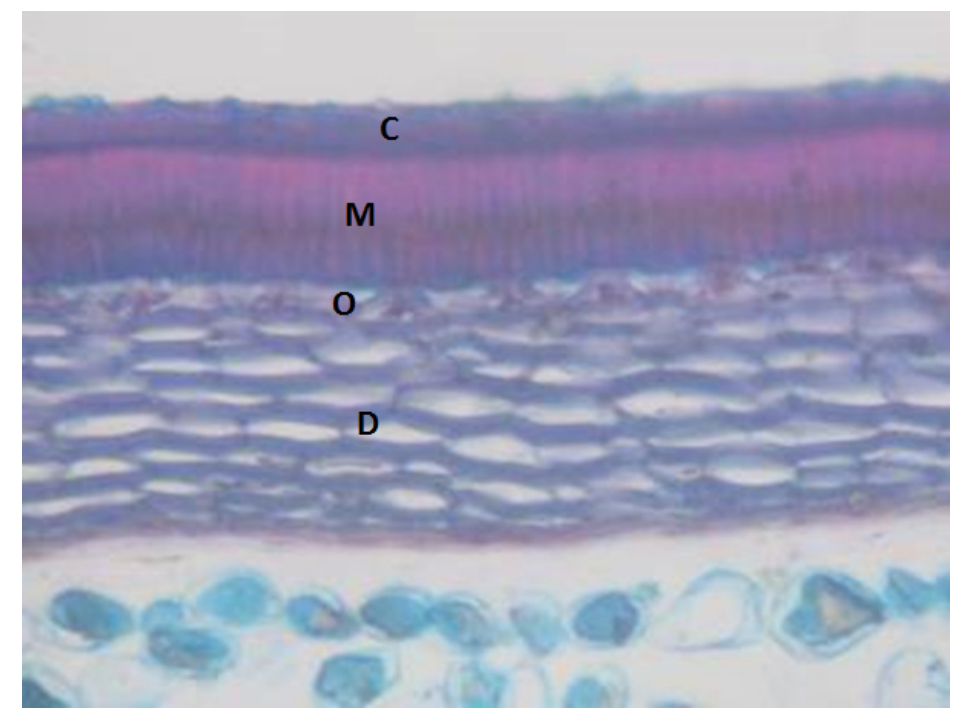

Figure 2. Seed coat anatomy of $S$. obtusifolia $(\mathrm{C}=$ Cuticle; $\mathrm{M}=$ Macrosclereids; $\mathrm{O}=$ Osteosclereids; $\mathrm{D}=$ Disintegrated parenchyma layers)

\section{Discussion}

The results of different treatments, namely concentrated sulphuric acid, $99 \%$ methanol, hydrogen peroxide $99 \%$ ethanol and $2 \%$ potassium nitrate indicated chemical scarification with $\mathrm{H}_{2} \mathrm{SO}_{4}$ enhanced germination when compared to other treatments (Figure 3). Treatment with concentrated sulphuric acid for a period of 10-30 minutes gave the highest germination (100\%) and this finding is supported by the reports of Sadat et al (2014) in Cassia fistula; Tambari and Aminu, (2015) in S. obtusifolia; Afshar, et al (2014) in dormant seeds of Canna indica L and Mensah and Agbagwa (2004) in seeds of Gmelina arborea, that chemical scarification with $\mathrm{H}_{2} \mathrm{SO}_{4}$ enhanced seed germination.

Enhancement of germination of seeds of $S$. obtusifolia treated with $\mathrm{H}_{2} \mathrm{SO}_{4}(100 \%$ after 10 minutes pretreatment $)$ as against intact seeds $(0 \%)$ may indicate oxidation of the seed coats by the acid with the resultant softening and rupturing of the seed coats. The softening of the seed coat permit the entry of water and diffusion of oxygen, thus initiating germination process in the seed and eventual protrusion of the radical and subsequent germination.

Other treatments with methanol, hydrogen peroxide, ethanol and potassium nitrate gave germinations ranging from $4.17 \%$ to $24 \%$ (Figure 3 ) as against control (intact seeds) with $0 \%$ germination. These germinations are considered low thus the treatments are considered ineffective in breaking seed dormancy and promoting seed germination. 


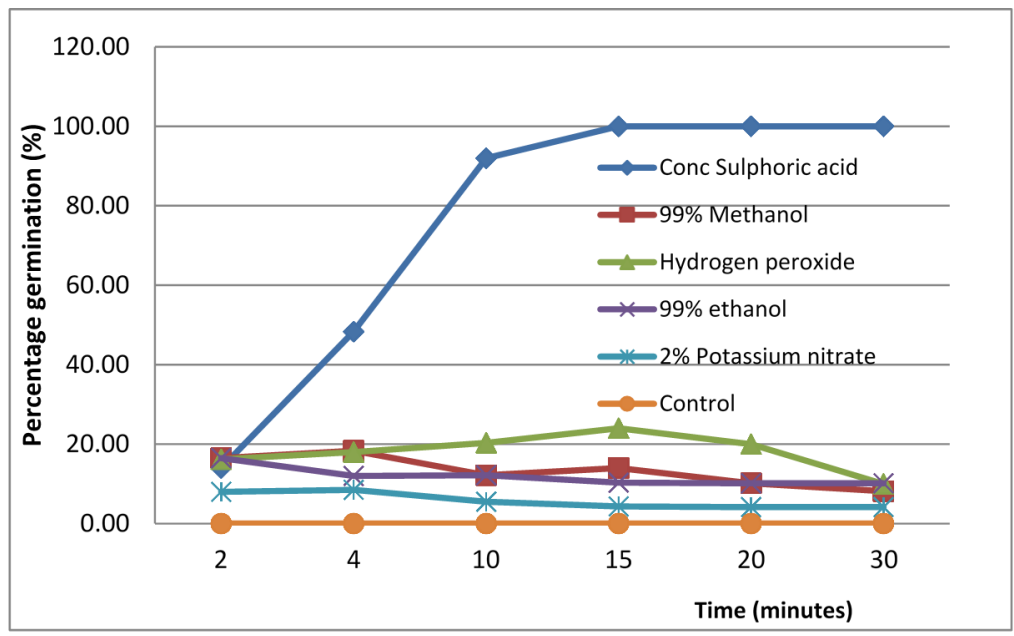

Figuure 3. Effects of different pretreatment methods on the germination of S. obtusifolia

The result of the water uptake (13.5\%) after 24 hours exposure supported the observation that the seed coat is primarily responsible for the dormancy of S. obusifolia seeds and prevents entry of water among other requirements for germination. Consequently rupturing of the seed coat breaks dormancy and promotes germination as noted with $\mathrm{H}_{2} \mathrm{SO}_{4}$ pre-treatment.

Baskin and Baskin (2005) reported that seeds that do not imbibe water have physical dormancy, this is considered the situation with S. obtusifolia seeds in view of the low water uptake observed in the seeds. The anatomy of the seed coat S. obtusifolia indicated hard impermeable seeds, the concentrated sulphuric acid acts to oxidize, degrade and often the coat to permit water uptake and gaseous exchange and remove the constraint imposed by the covering layers. Dormancy in the seeds of S. obtusifolia is of physical type and germination is constraint by the hard impermeable coverings.

\section{Conclusion}

Seed dormancy in S. obtusifolia species appears to be physical in nature (physical dormancy) as evidenced by the low water absorption of intact seeds; enhanced percentage germination of chemical scarification using of $\mathrm{H}_{2} \mathrm{SO}_{4}$, and the hard/impermeable cells of the seed coverings. The seed coat is considered a barrier to germination by preventing entry of water and diffusion of air and or mechanically inhibiting the protrusion of radicle.

\section{Acknolegdgement}

The authors wish to acknowledge and appreciate the efforts of the staff and menbers of the Department of Plant Science and Biotechnology, Faculty of Science, University of Port Harcourt and Miss Nkechi for providing laboratory assistance and other necessary assistance during this research work.

\section{References}

Abbott, T. P., Vaughn, S. F., Dowd, P. F., Mojthedi, H., \& Wilson, R. F. (1988). Potential uses of sicklepod (Cassia obtusifolia). Industrial Crops and Products, 8(1), 77-82. http://dx.doi.org/10.1016/s0926-6690(97)10010-3

Afsaneh, R., Farshd, Y., Bahram, N., Katayoun, H., \& Mohamad-Ali, H. (2012). A study of hydrogen peroxide effects on oriental beech (Fagus orientalis) nuts germination stimulation (Case study: Drazno region at eastern extreme of oriental beech in the Elborz Mountains, Iran). Annals of Biological Research, 3(10), 4728-4733.

Afshar, F. I., Ali, S. S., \& Mozhgan, S. (2014). Effect of $\mathrm{H}_{2} \mathrm{SO}_{4}$ on Seed Germination and Viability of Canna indica L. Ornamental Plant. International journal of Advanced Biological and Biomedical Research, 2(1), 223-229.

Agbagwa, I. O., Okoli, B. E., \& Ndukwu, B. C. (2007). Comparative Anatomy of Abrus Adanson Species in Parts of Tropical West Africa. Asian Journal of Plant Sciences, 6, 732-740. http://dx.doi.org/10.3923/ajps.2007. 732.740

Ajiboye, A. A. (2010). Dormancy and Seed Germination in Tamarindus indica (L). The Pacific Journal of Science and Technology, 11(2), 463-470 
Akobundu, I. O., \& Agyakwa, C. W. (1988). A Handbook of West Africa Weeds (2 $2^{\text {nd }}$ ed.). African Book Builders Ltd., Ibadan, Nigeria.

Al-Menaie, H. S., Al-Ragam, O., Al-Shatti, A., Mathew, M., \& Suresh, N. (2010). The effects of different treatments on seed germination of the Cassia fistula L. and Cassia nodosa Buch.-Ham. exRoxb. in Kuwait. African Journal of Agricultural Research, 5(3), 230-235.

Asghar, F. 1., Bahram, G., \& Hamed, J. J. (2014). Effects of Different Treatments on Seed Germination Improvement of Calotropispersica. Advances in Agriculture. http://dx.doi.org/10.1155/2014/245686

Baskin, C. C., \& Jerry, M. B. (2005). Seed dormancy in trees of climax tropical vegetation types. Tropical Ecology, 46(1), 17-28 (2005), International society for Tropical Ecology.

Berrie, A. M. M., \& Drennan, D. S. H. (1971). The Effect of hydration- dehydration on seed germination. New phytol., 70, 135-142. http://dx.doi.org/10.1111/j.1469-8137.1971.tb02518.x/pdf

Berrie, A. M. M. (1984). Germination and dormancy-In Advanced Plant Physiology. Pitams Publishing Limited. 128 Long Acre London.

Bewley, J. D., Bradford, K., Hilhorst, H., \& Nonogaki, H. (2013). Seeds: Physiology of Development, Germination and Dormancy (3rd ed.). New York: Springer-Verlag.

Bewley, J. D., \& Black, M. (1982). Physiology and biochemistry of seeds in relation to germination. Vol. 2, Viability, dormancy and environmental control. New York: Springer-Verlag.

Corbineau, F., Gouble, B., Lecat, S., \& Come, D. (1991). Stimulation of germination of dormant oat (Anastasia L.) seeds by ethanol and other alcohols. Seed Science Research, 1, 21-28.

Dorota, S. (2014). Effects of hydrogen peroxide treatment on the germination, vigour and health of Zinnia elegans seeds. Folia Hort., 26(1), 19-29. http://dx.doi.org/10.2478/fhort-2014-0002

El-Morsy, T. H. (2013). Antibiotic Properties of Leaf Extracts of Senna alexandrina (L). Journal of American Science, 9(1), 288-292.

Emongor, V. E., Mathowa, T., \& Kabelo, S. (2004). The effect of Hot water, Sulphuric acid, Nitric acid, Gibberelic acid and Ethephon on the germination of Corchorus (Corchorus tridens) seed. Journal of Agronomy, 3(3), 196-200. http://dx.doi.org/10.3923/ja.2004.196.200

Ettu, A. O., Senjobi, C. T., \& Ilusanya O. A. F. (2011). Antimicrobial Activity of Leaf Extracts of Senna occidentalis (L). Journal of Agriculture and Biological Sciences, 2(1), 026-030.

Gregorio, B., José, A. H., \& Pedro, D. (2012). Role of $\mathrm{H}_{2} \mathrm{O}_{2}$ in pea seed germination. Plant Signaling \& Behavior., 7(2), 193-195. http://dx.doi.org/10.4161/psb.18881

Hamid, R. B., \& Seyed, A. M. M. S. (2006). Effect of Gibberellic acid, Prechilling, Sulfuric acid and Potassium nitrate on seed germination and dormancy of Annual Medics. Pakistan Journal of Biological Sciences, 9(15), 2875-2880.

Harry-O'kuru, R. E., Payne-Wah, K. L., \& Busman, M. (2012). Medicinal Components Recoverable from Sicklepod (Senna obtusifolia) Seed: Analysis of Components by HPLC-MSn. Journal of Chromatography \& Separation Techniques. http://dx.doi.org/10.4172/2157-7064.S1-001

Hutchinson, J., Dalziel, J. M., \& Keay, R.W. J. (1954). Flora of West Tropical Africa; Vol. I Part I. Crown Agents for Oversea Governments and Administrations, London.

Idu, M., Omonhinmin, A. C., \& Onyibe, H. I. (2007). Determination of Phenology, Seed Germination and Development of Hura crepitans using Chemical Scarifications. International Journal of Botany, 3, 118-121. http://dx.doi.org/10.3923/ijb.2007.118.121

Ikeda, M. (1963). Studies on the viviparous germination of rice seed. Bulletin of the Faculty of Agriculture Kagoshima University, 13, 89-115.

Irfan, A., Fahad, M., Chaudhry, M. A., Shahzad, M. A. B., Amjad, H., \& Fawad, S. (2013). Ethanol Priming: An Effective Approach to Enhance Germination and Seedling Development by Improving Antioxidant System in Tomato Seeds. Acta Sci. Pol., Hortorum Cultus, 12(4), 129-137.

Irwin \& Barneby. (2016). Senna obtusifolia. http://tropical.theferns.info/viewtropical.php?id=Senna+obtusifolia 
Jerry, M. B., Xiaoying, N., \& Carol, C. B. (1998). A comparative study of seed dormancy and germination in an annual and a perennial species of Senna (Fabaceae). Seed Science Research, 8(4), 501-512. http://dx.doi.org/10.1017/S0960258500004475

Johnson, J. B., \& Raven, P. H. (2002). Biology. Mc Graw Hill U.S.A 2002: 801.

Kaufmann, M. R., \& Ross, K. J. (1970). Water Potential temperature and Kinetin effects on seed germination in soil and solute systems. Am J Bot., 57, 413-419.

Kim, S. J, Kim, K. W, Kim, D, S, Kim, M. C, Jeon, Y. D, Kim, S. G, ... Um, J. Y. (2011). The protective effect of Cassia obtusifolia on DSS-induced colitis. Am. J. Chin. Med., 39(3), 565-77.

Mensah, S. I. (1984). Studies on the Germination and Dormancy of Polygonum Persicaria, L. (Unpublished Ph.D's Thesis). University of Glasgow- United Kingdom.

Mensah, S. I., \& Agbagwa, I. O. (2004). Breaking Dormancy in Gmelina Arborea Roxb. Through Treatment of Seeds with chemical substances And Alternating Temperature. Journal of Biological Research and Biotechnology, 2(1). http://dx.doi.org/10.4314/br.v2i1.28542

Mensah, S. I., \& Agbagwa, I. O. (2001). The Responses of Seed of Capsicum frutescens to the exogenous application of some germination promoters. J. Agric. Biotech. Environ., 3(1/2), 43-47.

Mohammad R., Faezeh Z., \& Vajihe A. (2014). Effects of chemical treatments and environmental factors on seed dormancy and germination of shepherd's purse (Capsella bursa-pastoris (L.) Medic.). ActaBotanicaBrasilica, 28(4), 495-501. http://dx.doi.org/10.1590/0102-33062014abb3337

Msaakpa, T. S., Obasi, M. O., \& Kortse P. A. (2013). Dormancy Breaking and Germination of Castor (Ricinus communis L.) Seed. ARPN Journal of Agriculture and Biological Science, 8(5), 2006-2013. Asian Research Publishing Network (ARPN).

Nalawadi, U. G, Bhandary, K. R., \& Chandrashekar, T. (1977). Germination of Cassia fistula (Linn.) seeds could be improved by treatment with sulphuric acid for $20 \mathrm{~min}$. Curr. Res. Hortic. Abst., 4(3), 42-43.

Ramamoorthy, K., Rajendran, C., \& Sivasubramanian, S. (2005). Seed treatment for alleviation of hard seededness in senna (Cassia angustifolia L.). Adv Plant Sci., 18(1), 429-430.

Rolston, M. P. (1978). Water impermeable seed dormancy. Bot. Rev., 44, 365-398.

Sadat, E., Babalola, O., Shonubi, O., \& Olubukanala, T. O. (2014). Seed Dormancy in Cassia fistula Linn. Population from Nigeria. Journal of American Science, 2014(10), 85-93. Retrieved from http://www.jofamericanscience.org

Salehi, M. R., Ashiri F., \& Salehi, H. (2008). Effect of Different Ethanol Concentrations on Seed Germination of Three Turfgrass Genera. Advances in Natural and Applied Sciences, 2(1), 6-9.

Sushma, R., \& Sardana, S. (2013). Comparative Pharmacognostical Studies of Leaves of Three Cassia species. Research Journal of Pharmaceutical Sciences, 3(7), 1-8.

Tajbakhsh, M. (1996). Seed, Identification, Certification and its control (pp. 151). Ahrar Tabriz Press. (In Persian)

Tambari, U., \& Aminu, A. M. (2015). Effect of Different Seed Treatment Methods on the Germination of Senna obtusifolia in Sudan Savanna Ecosystem, Nigeria. American Academic \& Scholarly Research Journal, 7(2). Retrieved from https://www.questia.com /library/journal/1P3-3649122401

Taylorson, R. B., \& Hendricks, S. B. (1979). Overcoming dormancy in seeds with ethanol and other anesthetics. Planta, 145, 507-510.

Yushi, I., Kouhei, Y., Tomoya, T., Takashi, Y., \& Mari, I. (2008). Hydrogen peroxide scavenging regulates germination ability during wheat (Triticum aestivum L.) seed maturation. Plant Signalling \& Behaviour, 3(3), 183-188.

\section{Copyrights}

Copyright for this article is retained by the author(s), with first publication rights granted to the journal.

This is an open-access article distributed under the terms and conditions of the Creative Commons Attribution license (http://creativecommons.org/licenses/by/3.0/). 